\title{
The Effect of Social Media Marketing and Brand Awarness on Purchase Decisions With Viral Marketing As Intervening Variables on Janji Jiwa Coffee Consumers Among Students Using Social Media Area Jabodeta
}

\author{
Muhammad Nurfauzi Awaludin ${ }^{* *}$ and Sigit Sukmono ${ }^{2}$ \\ ${ }^{1,2}$ Universitas Gunadarma, Depok, Indonesia
}

\begin{abstract}
The purpose of this study was to analyze the influence of social media marketing and brand awareness on purchasing decisions with viral marketing as an intervening variable in Janji Jiwa coffee consumers among students who use social media in Jabodeta. convenience sampling with samples used as many as 214 respondents to fill out an online questionnaire with certain criteria. This research uses two independent variables, namely social media marketing and brand awareness, the dependent variable is the purchase decision and as an intervening variable (mediation), namely viral marketing. The method used in this study uses path analysis which is the development of multiple linear regression andprocessed using SPSS software. From the research results, it is known that social media marketing has an effect on purchasing decisions both directly and indirectly through viral marketin mediation, and brand awareness influences purchasing decisions both directly and indirectly through viral marketing mediation. Of the two, the direct influence on purchasing decisions is greater than the indirect effect through viral marketing mediation.
\end{abstract}

Keywords: Brand Awarness, Purchasing Decisions, Social Media Marketing, Viral Marketing.

\section{Introduction}

The world of marketing has entered a revolutionary new era. To increase the globalization of the world economy in broad market opportunities for companies. This of course leads to competition for market players to achieve better performance. While the effectiveness of traditional marketing communications has decreased, new methods of marketing are experiencing significant growth. This new method is known as "Digital Marketing or Digital Marketing" which combines psychological, humanistic, anthropological and technological factors through multimedia with a large capacity and more interactive. The result is a new chapter of interaction between producers, markets and consumers, through the technology (cellular) media as the dominant element. Digital Marketing can simplify the process of marketing a product no longer hindered by barriers such as distance, time and language. The convenience offered by this can also make it easier for businesses to expand their business by utilizing Digital Marketing (Chua, Rashid, Law, Hamizah, Khairul, and Chua, 2010). With digital marketing communication and transactions can be done at any time / real time and can be global or global. With the large number of internet users that include a marketplace or chat-based social media which is growing and increasing every day, it opens up opportunities for every company to develop its market in the hands of a smartphone. With digital marketing communications and transactions can be done at any time / real time and can be global or global. With the large number of internet users that include a marketplace or chat-based social media, which are increasing every day, it opens up opportunities for each company to develop its market in the hands of a smartphone. With digital marketing communication and transactions can be done at any time / real

* Corresponding author. Email address: fauzmalik29@gmail.com 
time and can be global or global. With the large number of internet users that include a marketplace or chat-based social media, which are increasing every day, it opens up opportunities for each company to develop its market in the hands of a smartphone.

Based on Kemp's latest report in We Are Social, in 2020 it was stated that there were 175.4 million internet users in Indonesia. Compared to the previous year, there was an increase of $17 \%$ or 25 million internet users in this country. Based on the total population of Indonesia, which amounts to 272.1 million people, it means that $64 \%$ of Indonesia's population has experienced access to cyberspace. Percentage of internet users aged 16 to 64 who own each type of device, including mobile phones (96\%), smartphones (94\%), non-smartphone mobile phones (21\%), laptops or desktop computers $(66 \%)$, table $(23 \%)$, game consoles $(16 \%)$, to virtual reality devices $(5.1 \%)$. In this report it is also known that currently 338.2 million Indonesians who use cell phones. Likewise data that is no less interesting, there are 160 million active users of social media (medsos). When compared to 2019, this year We Are Social found an increase of 10 million Indonesians who are active on social media. Indonesia itself is in third place with a population growth that accesses the internet by 17 percent in the past year. This figure is equal to 25.3 million new internet users in a year. Indonesia's ranking is only behind India and China.

Today the internet is not limited only to the use of information that can be accessed through one medium but can also be used as a means of conducting transactions that can lead to a new marketplace and a broad business network that is not limited by place and time. The increasing number of internet users in Indonesia makes it a very good market for players in the e-commerce / online shopping industry. So it is not surprising that in Indonesia there are large e-commerce and marketplaces with fantastic capital for the size of the industry in Indonesia, namely Matahari Mall, Bukalapak, Lazada, Blibli, Tokopedia, Shopee and others. Not only official shopping sites have sprung up, but there are also those that only use personal accounts from ecommerce players on social media such as Instagram, Facebook, Whatsapp,

One of the strategies in digital marketing is the use of Social Media Marketing. Many companies think that just applying social media marketing can make it easier and add value to their products, cheaper and more efficiently. The impact on sales will be great if many consumers and customers visit the site and know the brands that are being offered. One of the goals of effective marketing is to introduce the existence of a product into top of mind and become the choice of consumers to buy the product offered. Besides digital marketing, of course there are other things that should not be forgotten, such as brands. Brand (brand) plays an important role in marketing. There is quite a difference between a product and a brand. A product is just something that a factory produces, whereas a brand is something that consumers buy. If a product can be easily imitated by competitors, then the brand always has a unique characteristic that is relatively difficult to copy. Brand is closely related to perception, so that in fact the competition that occurs between companies is a battle of perceptions and not just a battle of products (Suciningtyas, 2012). Brand is actually a seller's promise to consistently provide certain features, benefits and services to buyers. The best brands provide quality assurance (Rangkuti, 2004). Therefore it is very important for a company to build brand awareness (brand awareness) in consumers. Brand awareness is the ability of consumers to identify a brand in different conditions, it can be done with brand recognition and recollection of a particular brand.

With the existence of Digital Marketing and Brand Awarness, it is hoped that it can stimulate consumers in forming purchasing decisions for the products we offer. According to Kotler (2015) the notion of a purchase decision is the action of consumers to want to buy or not to a product. The decision-making process to buy a product starts from identifying the problem, searching for information, evaluating several alternatives, which in turn will create a purchase decision and form post-purchase behavior. 
Seeing the development of business through the internet or social media, and what is currently being developed is also called viral marketing, or WOM (Word of Mouth Marketting). Viral marketing is a technology that uses Word of Mouth Marketting by using a variety of content which is expected to strengthen the influence of social media marketing and brand awareness on purchasing decisions. viral marketing uses the internet network, which means that they are not face to face in transactions. So here the company must be able to make a consumer or customer trust in the company. There are various ways that companies take, such as offering a product that can convince consumers to make purchasing decisions, create attractive website designs,

Kopi Janji Jiwa is a local coffee that has many fans. Janji Jiwa itself has expanded to dozens of cities with hundreds of outlets. In fact, this coffee brand has won the Indonesian World Record Museum (MURI) award for "The Fastest Coffee Shop Growth in One Year" in 2019. The furthest coffee shop Janji Jiwa is in the city of Timika, Papua. The founder and CEO, Billy Kurniawan, founded Kopi Janji Jiwa since 2018 under the auspices of the Jiwa Group at PT. Luna Boga Narayan (Fajria in wartaekonomi.co.id).

Factors that can influence decisions in this study include social media marketing, brand awareness and viral marketing which are used as intervening variables. Companies need to consider the market aspects that exist in social media and create interesting content in order to improve consumer purchasing decisions. Based on research results Ansari, Ansari, Ghori, and Kazi (2019) as well as research from Farih, Jauhari, and Widodo (2019) state that social media marketing has an effect on purchasing decisions.

To improve purchasing decisions, another thing that needs to be considered is brand awareness so that consumers recognize the product or product brand we are selling. Based on research conducted by Ansari et al. (2019) show that brand awareness and purchasing decisions have a weak influence. Then research from Kurniasari and Agung (2018) shows that brand awareness affects purchasing decisions.

Viral marketingusing the internet network, which means that they do not meet face to face in transactions. So here the company must be able to make a consumer or customer trust in the company. There are various ways that companies do, such as offering a product that can convince consumers to make purchasing decisions. Based on research Wiludjeng and Nurlela (2013) viral marketing influence on purchasing decisions.

Based on the description above, it can be seen that purchasing decisions are important things for business people. Thus the authors are interested in conducting research on the factors that trigger purchasing decisions, especially those measured by social media marketing and brand awareness strengthened by viral marketing as an intervening. Therefore, a research will be conducted with the title "The Influence of Social Media Marketing and Brand Awarness on Purchasing Decisions with Viral Marketing as an Intervening Variable in Consumers of Kopi Janji Jiwa" among students who use social media in the Jabodeta area.

\section{Literature Review}

\section{Social Media Marketing}

According to Kaplan and Haenlein (2010), social media is defined as a group of internet-based applications built on the basis of Web 2.0 ideology and technology. Web 2.0 is the foundation of social media platforms. Social media itself consists of many different forms, such as social networks, internet forums, weblogs, social blogs, micro blogging, wikis, prodcasts, pictures, videos, ratings and social bookmarking. Social media marketing is a form of marketing that is used to create awareness, recognition, memory and even action against a brand, product, business, individual, or group either 
directly or indirectly by using tools from the social web such as blogging, microblogging, and social networking. (Kurniasari \& Agung, 2018).

According to Ristania and Jerry (2015) indicators that can be used to measure social media marketing include the following:

1) Promotion range

2) The quantity of updates in the media

3) Message quality

\section{Brand Awarness}

According to Hermawan (2014) Brand awareness is the ability of a potential buyer to recognize or recall a brand that is part of a product category. Consciousness also influences perception and behavior. So if the awareness is very low then it is almost certain that the brand equity is also low. The role of brand awareness in overall brand equity depends on the level of awareness achieved by a brand. There are four levels of consumer memory regarding brands from the lowest level to the highest level as well as an indicator used in measuring the brand awareness variable (Durianto, 2004)

1) Unware of brand (not aware of the brand)

2) Brand recognition (brand recognition)

3) Brand recall (brand recall)

4) Top of mind (peak of mind)

\section{Buying decision}

According to Suharno (2010) a purchase decision is a stage where the buyer has made his choice and made a purchase of a product, as well as consumes it. Decision making by consumers to purchase a product begins with an awareness of their needs and desires. According to Kotler (2007) a purchase decision is "the act of a consumer to want to buy or not to a product". The definition of a purchase decision, according to Kotler \& Armstrong (2015), is a stage in the buyer's decision-making process where consumers actually buy.

According to Kotler (2008) the purchasing decision-making process consists of five stages, which are presented in the following figure:

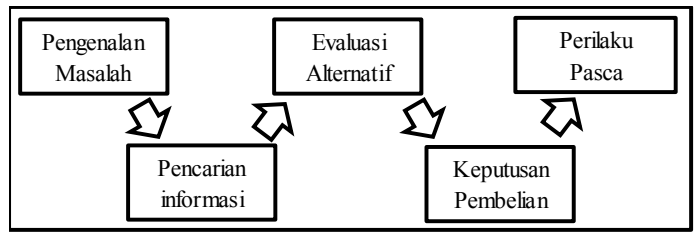

Figure 1 Stages in a Purchase

Source: Kotler (2008)

The process image is based on the assumption that consumers will carry out all five steps for the purchases they make in a given situation. The indicators used (Akbar $\&$ Sugiono, 2011) are as follows:

1) Planning a Purchase

2) Looking for more information on a product

3) According to his wishes

4) Confidence in buying

5) Adds a sense of trust

6) Awareness of needs.

\section{Viral Marketing}

The term viral marketing was coined by Rayport in an article in 1996 entitled "The Virus of Marketing". The article was written what if the virus was used as a marketing program. Because the marketing message will be spread using only very little time, unnecessary budgets are too large and the impact is very wide (Farih et al., 2019). According to Kotler and Armstrong (2004), viral marketing is the internet marketing version of the use of word of mouth marketing, which is closely related to creating messages or marketing methods that are so contagious that customers want to 
convey them to their friends. According to Skrob (2005), components in viral marketing as well as indicators used include consumer, buzz, and supporting conditions.

\section{Research Methodology}

The object of research is an attribute or nature or value of people, objects or activities that have certain variables that are determined to be studied and drawn conclusions. From the above understanding that the definition of the object of research is something that is the target of scientific research. The research object in this study were students using Social Media in Jabodeta (Jakarta Bogor Depok Tangerang).

Population

According to Sugiyono (2011) population is a generalization area consisting of objects / subjects that have certain qualities and characteristics that are determined by researchers to be studied and then draw conclusions. So the population is not only people, but also objects and other natural objects. Population is also not just the number that is in the object / subject being studied, but includes all the characteristics / properties possessed by the subject or object. The population in this study were students and female students using social media in Jabodeta.

Sample

According to Sugiyono (2016) the sample is the part or number and characteristics of the population. If the population is large, and it is impossible for the researcher to study everything in the population, for example because of limited funds, energy and time, the researcher will take a sample from that population. The method used in sampling is non-probability sampling, which is a sampling method that does not provide equal opportunities or opportunities for each element or member of the population to be selected as samples for certain considerations (Sugiyono, 2016). Sampling was carried out using convenience sampling technique, which is a technique used to take samples of people who are easiest to find or are asked to fill out a questionnaire.

In this study the minimum number of samples that must be taken, using the sampling technique according to Joreskog and Sorbom (Riduwan \& Kuncoro, 2012), where the minimum sample determination can be seen in table 1 below:

Table 1 Minimum sample size and number of Joreskog and Sorbom variables

\begin{tabular}{cc}
\hline Number of Variables & Minimum Sample Size \\
\hline 3 & 200 \\
5 & 200 \\
10 & 200 \\
15 & 360 \\
20 & 630 \\
25 & 975 \\
30 & 1395 \\
\hline
\end{tabular}

Source: Riduwan and Kuncoro (2012)

If you look at table 1, the minimum sample size taken in this study is 200 respondents because the number of variables tested was 4 variables (between 3 and 5 variables). This number can increase because the more samples the better.

\section{Types and Sources of Data}

The data used in this study are primary data and secondary data. According to Syafizal (2010) primary data is data that is collected by individuals or an organization directly from the object under study and for the purposes of the study concerned, which can be in the form of interviews and observations. In this study, researchers used a questionnaire regarding questions distributed to respondents.

Secondary data is data obtained or collected and put together from previous studies or published by various other agencies according to Syafizal (2010). Secondary 
data used includes library material in the form of books, journals and other media that are related to the study material in this study.

\section{Method of collecting data}

The data collection method was carried out by distributing online questionnaires. The questionnaire is a data collection technique which is done by giving a set of written questions to respondents to answer them (Sugiyono, 2011). The previous questionnaire has been structured with several alternative answer choices which are then given a score for each answer. Questions are made in the form of a questionnaire using a Likert scale. According to Sugiyono (2011) the Likert scale is a scale used to measure the attitudes, opinions and perceptions of a person or group of people about social events or symptoms. The method of measurement is by confronting the respondent with a question and then being asked to answer it, where the value of each answer has a different value.

\section{Research methods}

According to Sugiyono (2011) the research method is basically a scientific way to get data with specific purposes and uses. The method used in this research is the Verification Method, according to Sugiyono (2016) argues that verification is a study aimed at testing theory and trying to produce a scientific method, namely the status of the hypothesis in the form of a conclusion, whether a hypothesis is accepted or rejected. This method is used to test the truth of the hypothesis, namely how the influence of social media marketing and brand awareness on the decision to buy Janji Jiwa coffee with viral marketing as a mediating variable. Analysis of the data used in this study using the method of path analysis (path analysis) carried out with multiple linear regression analysis model using SPSS version 20 software.

\section{Results and Discussion}

\section{Research Overview}

Kopi Janji Jiwa. Janji Jiwa is an authentic Indonesian coffee shop owned by PT. Luna Boga Narayan, which was first founded by Billy Kurniawan as a Business Owner at ITC Kuningan in 2018. Kedai Kopi Janji Jiwa started as the owner of this beverage business, who had a passion in the coffee sector. This brand was issued as a promise from the bottom of his heart to serve coffee as one of his passions. Janji Jiwa coffee serves a wide selection of local Indonesian coffee at affordable prices that adopt the fresh-to-cup concept and is known for its 'grab and go' system in the form of small outlets for sales only.

\section{Instrument Quality Test}

In testing the quality of the instrument using validity and reliability tests which are processed using SPSS (Statistical Package for Social Science) version 20.

\section{Validity test}

The validity test is useful to find out whether there are statements on the questionnaire that should be removed / replaced because they are considered irrelevant. If rcount $>$ rtabel $=$ valid and if rcount $<$ rtabel $=$ invalid.

Table 2 Summary of Validity Test Results

\begin{tabular}{|c|c|c|c|}
\hline Statement Items & r hitung & $r$ table & Information \\
\hline \multicolumn{4}{|c|}{ Social Media Marketing } \\
\hline Item 1 & 0.814 & 0.2787 & Valid \\
\hline Item 2 & 0.824 & 0.2787 & Valid \\
\hline Item 3 & 0.824 & 0.2787 & Valid \\
\hline Item 4 & 0.820 & 0.2787 & Valid \\
\hline Item 5 & 0.800 & 0.2787 & Valid \\
\hline Item 6 & 0.861 & 0.2787 & Valid \\
\hline Brand Awarness & & & \\
\hline
\end{tabular}




\begin{tabular}{lccl}
\hline Item 1 & 0.523 & 0.2787 & Valid \\
Item 2 & 0.614 & 0.2787 & Valid \\
Item 3 & 0.772 & 0.2787 & Valid \\
Item 4 & 0.620 & 0.2787 & Valid \\
Item 5 & 0.735 & 0.2787 & Valid \\
\hline Buying decision & & & \\
\hline Item 1 & 0.818 & 0.2787 & Valid \\
Item 2 & 0.615 & 0.2787 & Valid \\
Item 3 & 0.840 & 0.2787 & Valid \\
Item 4 & 0.760 & 0.2787 & Valid \\
Item 5 & 0.792 & 0.2787 & Valid \\
Item 6 & 0.832 & 0.2787 & Valid \\
\hline Viral Marketing & & & \\
\hline Item 1 & 0.903 & 0.2787 & Valid \\
Item 2 & 0.823 & 0.2787 & Valid \\
Item 3 & 0.827 & 0.2787 & Valid \\
Item 4 & 0.776 & 0.2787 & Valid \\
Item 5 & 0.887 & 0.2787 & Valid \\
Item 6 & 0.837 & 0.2787 & Valid \\
\hline \multicolumn{4}{l}{ Source: Primary data processed, 2020 }
\end{tabular}

The results of the validity test on all items of each variable carried out on 50 respondents can be declared valid, because the minimum requirement for a statement to be said to be valid is greater than the $r$ table which is valued at 0.2787 has been fulfilled.

\section{Reliability Test}

According to Ghozali (2013), reliability testing in this study is to use the Cronbach's Alpha formula which shows the answer must be $>0.60$. Conversely, if the Cronbach's Alpha value of a variable is $<0.60$, the question item is not reliable.

Table 3 Reliability Test Results

\begin{tabular}{lccc}
\hline \multicolumn{1}{c}{ Variable } & Cronbach's Alpha & Cut of Value & Information \\
\hline Social Media Marketing & 0.905 & 0.60 & Reliable \\
Brand Awarness & 0.656 & 0.60 & Reliable \\
Purchase Decisions & 0.870 & 0.60 & Reliable \\
Viral Marketing & 0.916 & 0.60 & Reliable \\
\hline
\end{tabular}

Source: Primary data processed, 2020

Based on Table 3, the results of the reliability test carried out on 50 respondents produced values, namely social media marketing of 0.905 , brand awareness of 0.656 , purchasing decision of 0.870 and viral marketing of 0.916 . The minimum requirements for questions to be declared reliable are greater than 0.60 have been met, so it can be concluded that social media marketing, brand awareness, purchasing decisions and viral marketing can be declared reliable.

\section{Classic assumption test}

The classic assumption test is to provide certainty that the regression equation obtained has accuracy in estimation, is unbiased and consistent. It is possible that the actual data does not fulfill all of these classic assumptions. The classic assumptions in this study are:

\section{Normality test}

According to Ghozali (2013), the normality test aims to test whether in the model, confounding or residual variables have a normal distribution. Confounding variables from a regression are required to be normally distributed, so the variables under study are also normally distributed. 
Table 4 Normality Test Results

\begin{tabular}{lcc}
\hline Unstandardized Residual & Asymp. Sig. & Information \\
\hline Equation 1 & 0.324 & Normally distributed data \\
Equation 2 & 0.638 & Normally distributed data
\end{tabular}

Source: Primary data processed, 2020

The Kolmogorov-Smirnov calculation results show that the respective significance values from equation 1 and equation 2 all values $>0.05$. Thus, it can be concluded that the regression model is feasible because it fulfills the assumption of normality or it can be said that the distribution of research data is normally distributed. Multicollinearity Test

The multicolonierity test was carried out by looking at the Variance Inflation Factor (VIF) value and the Tolerance value on the SPSS multicolonierity test results. The cut off value that is commonly used to indicate multicolonierity is the Tolerance value $>0.10$ or the same as the VIF value $<10$ (Ghozali, 2013). The multicolonierity test results can be seen briefly in table 5 as follows:

Table 5 Multicollinearity Test Results

\begin{tabular}{lccl}
\hline \multicolumn{1}{c}{ Variable } & Tolerance & VIF & Information \\
\hline Equation 1 & & & \\
\hline Social Media Marketing & 0.588 & 1,701 & Multicolonierity does not occur \\
Brand Awareness & 0.588 & 1,701 & Multicolonierity does not occur \\
\hline Equation 2 & & & \\
\hline Social Media Marketing & 0.570 & 1,753 & Multicolonierity does not occur \\
Brand Awareness & 0.469 & 2,131 & Multicolonierity does not occur \\
Viral Marketing & 0.597 & 1,675 & Multicolonierity does not occur \\
\hline \multicolumn{4}{l}{} \\
& Source: Primary data processed, 2020
\end{tabular}

Based on table 5 above, it shows that each of the variables both from equations 1 and 2 has a tolerance value $>0.10$ and a VIF value $<10$. This indicates that there is no multicollinearity problem in the regression model, so that it meets the regression analysis requirements.

\section{Heteroscedasticity Test}

To detect the heteriskedasticity of the significance level, the Glejser test or absolute resudual data can be used. If the significance level is above $5 \%$, it means there is no heteroscedasticity, but if it is below 5\%, it means that there are symptoms of heteroscedasticity (Ghozali, 2013). The results of the heteroscedasticity test can be seen in table 6 below:

Table 6 Heteroscedasticity Test Results

\begin{tabular}{llll}
\hline \multicolumn{1}{c}{ Variable } & Don't count & Sig. & Information \\
\hline Equation 1 & & & \\
\hline $\begin{array}{l}\text { Social Media } \\
\text { Marketing }\end{array}$ & 0.882 & 0.379 & Heteroscedasticity does not occur \\
Brand Awareness & 0.170 & 0.865 & Heteroscedasticity does not occur \\
\hline Equation 2 & & & \\
\hline Social Media & 1,067 & 0.287 & Heteroscedasticity does not occur \\
Marketing & & 0.407 & Heteroscedasticity does not occur \\
Brand Awareness & -0.830 & 0.078 & Heteroscedasticity does not occur \\
Viral Marketing & $-1,773$ & 0
\end{tabular}

Source: Primary data processed, 2020 
Based on the results of the analysis as in table 6 above, it can be seen that each variable both in equations 1 and 2 has a significance value ( $p$ value) $>0.05$, it can be concluded that each variable does not contain heteroscedasticity so that it meets the requirements in regression analysis.

\section{Determination Coefficient Test}

The coefficient of determination (R2) is used to measure the ability of the model to explain the variation in the dependent variable. The coefficient of determination is between 0 and 1 .

Table 7 Test Result of the coefficient of determination

\begin{tabular}{lrrrrr}
\hline \multicolumn{5}{c}{ Model Summary } \\
\hline Model & R & R Square & $\begin{array}{c}\text { Adjusted R } \\
\text { Square }\end{array}$ & $\begin{array}{l}\text { Std. Error of } \\
\text { the Estimate }\end{array}$ \\
\hline 1 & $.792 \mathrm{a}$ & .628 & .623 & 2,662 \\
\hline \multicolumn{4}{c}{ Source: Primary data processed, 2020}
\end{tabular}

From the analysis of the coefficient of determination (R2), it is known that the $\mathrm{R}$ Square value is 0.628 . This relationship will be perfect $(100 \%)$ or close if other independent variables are included in the model. This means that social media marketing, brand awareness and viral marketing for Kopi Janji Jiwa consumers explains $62.8 \%$ of purchasing decisions among Jabodeta students and the remaining $37.2 \%$ is explained by other variables outside the model.

Path Analysis

Path analysis is used to test the effect of the intervening variables. Path analysis is an extension of multiple linear analysis. The path analysis carried out using regression analysis in SPSS 20.0 software obtained the results shown in table 8 as follows:

Table 8 Results of Path Analysis of the Regression Equation 1

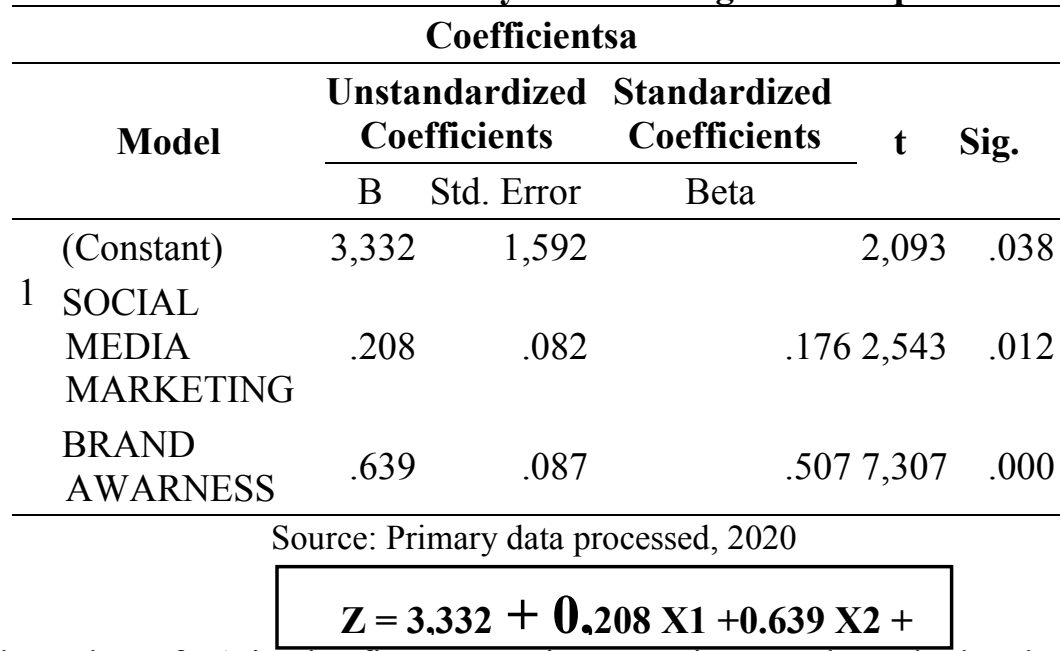

The value of e1 in the first regression equation can be calculated using the formula $\mathrm{e} 1=$. The value of $\mathrm{R}$ square 1 (R21) means the magnitude of the R square value in the first equation, the value of $\mathrm{R} 21$ can be seen in table $4: 18$ below: $\sqrt{1-\mathrm{R} 21}$ 
Table 9 Result of R Square Value 1

\begin{tabular}{lcccc}
\hline \multicolumn{5}{c}{ Model Summary b } \\
\hline Model & R & R Square & $\begin{array}{c}\text { Adjusted R } \\
\text { Square }\end{array}$ & $\begin{array}{c}\text { Std. Error of the } \\
\text { Estimate }\end{array}$ \\
\hline 1 & $.635 \mathrm{a}$ & .403 & .397 & 3,670 \\
\hline \multicolumn{4}{c}{ Source: Primary data processed, 2020 }
\end{tabular}

So that the value of el can be calculated as e $1=\sqrt{1-0,403}$ and the result is 0.635 . The value of $\mathrm{e} 1$ is entered into the regression equation 1 above to become $\mathrm{Z}=$ $3,332+0.208 \mathrm{X} 1+0.639 \mathrm{X} 2+0.635$. This means that if the social media marketing score increases by one unit, it will increase the viral marketing score felt by consumers by 0.208 with an error of 0.635 and if the brand awareness score increases by one unit, it will increase the viral marketing score felt by consumers by 0.639 with an error of 0.635 .

Table 10 Results of Path Analysis of Regression Equations 2

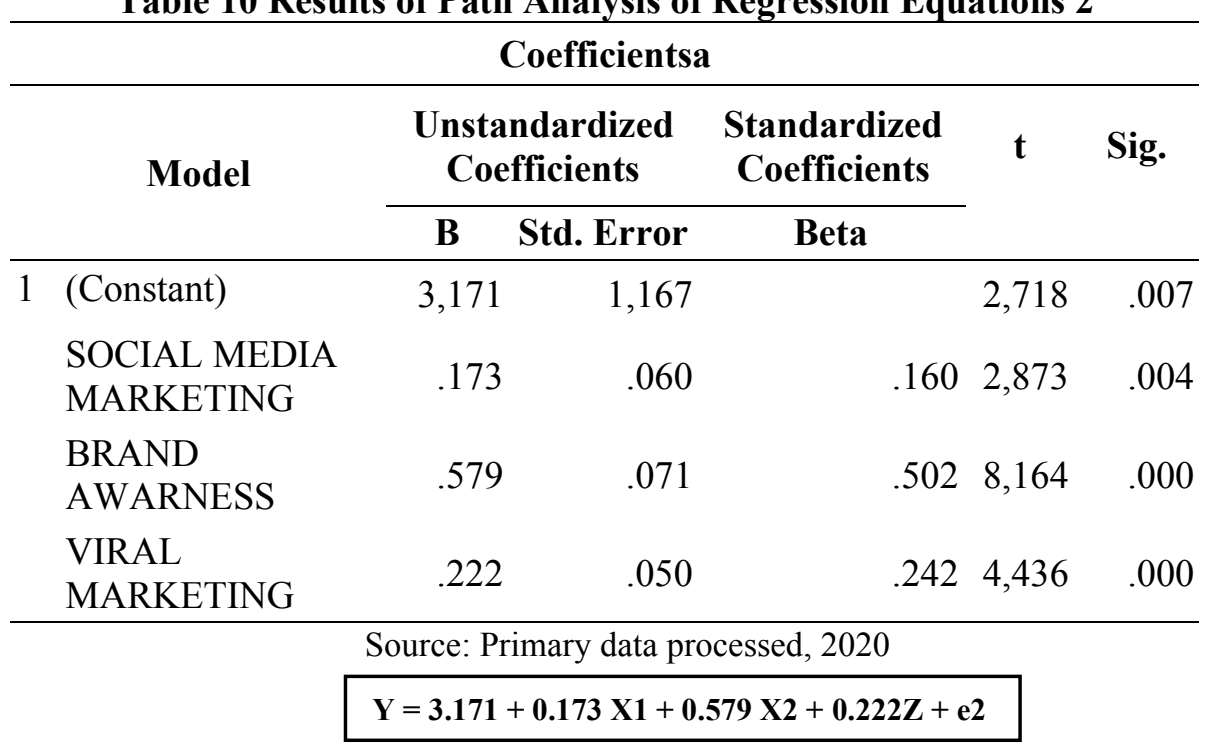

The value of e 2 in the second regression equation can be calculated using the formula $\mathrm{e} 2=$. The value of $\mathrm{R}$ square 2 (R22) means the magnitude of the R square value in the second equation, the value of R22 can be seen in table 4:20 below: $\sqrt{1-\mathrm{R} 22}$

Table 11 Result of R Square Value 2

\begin{tabular}{lcccc}
\hline \multicolumn{4}{c}{ Model Summary b } \\
\hline Model & R & R Square & $\begin{array}{l}\text { Adjusted } \\
\text { R Square }\end{array}$ & $\begin{array}{l}\text { Std. Error of } \\
\text { the Estimate }\end{array}$ \\
\hline 1 & $.792 \mathrm{a}$ & .628 & .623 & 2,662 \\
\hline \multicolumn{4}{c}{ Source: Primary data processed, 2020}
\end{tabular}

So that the value of $\mathrm{e} 2$ can be calculated as $\mathrm{e} 2=\sqrt{1-0,628}$ and the result is 0.610 . The value of $\mathrm{e} 2$ is entered into the regression equation 2 above, so the equation becomes $\mathrm{Y}=3.171+0.173 \mathrm{X} 1+0.579 \mathrm{X} 2+0.222 \mathrm{Z}+0.610$. It means scoresocial media marketingincreasing by one unit will increase the purchase decision score by 0.173 with an error of 0.610 . Furthermore, if the brand awareness score increases by one unit, it will increase the purchase decision score felt by consumers by 0.579 with an error of 0.610 and if the viral marketing score felt by consumers increases by one unit it will also increase the purchase decision score by 0.222 with an error of 0.610 . Thus it can be seen that the path analysis model of the two equations above is as follows: 


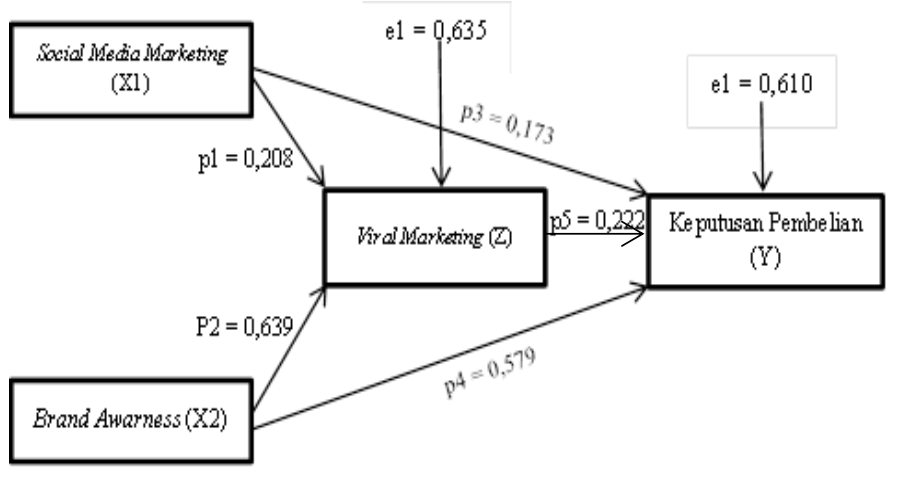

Figure 2 Path Analysis Model

Source: Primary data processed, 2020

\section{T test}

1) Direct Social Media Marketing Influence on Purchasing Decisions of Janji Jiwa Cofee Consumers among Jabodeta Students.

Based on the results of the analysis of the influence of social media marketing on purchasing decisions, the Sig. 0.04 with a beta coefficient value of 0.173 . Sig value. $0.04<0.05$. This result means that social media marketing has a significant positive effect on purchasing decisions. The magnitude of the influence of promotion through social media on purchasing decisions is 0.173 .

Social media marketingplaying a major role in this technology driven era, powerful content will persuade consumers towards the desired result, namely making purchasing decisions. The more appropriate promotion through social media can improve purchasing decisions. This research is in line with research conducted by Ristania and Jerry (2014) as well as Ansari et al. (2019) which state that social media marketing affects purchasing decisions.

2) Direct Brand Awareness Influence on Purchasing Decisions on Janji Jiwa Cofee Consumers among Jabodeta Students.

Based on the results of the analysis of the influence of brand awareness on purchasing decisions, the Sig. As big as 0,000 with a beta coefficient value of 0.579 . Sig value. $0.000<0.05$. This result means that brand awareness has a significant positive effect on purchasing decisions. The magnitude of the influence of promotion through social media on purchasing decisions is 0.579 .

The results of this study indicate that if consumers are well aware of the brand then there is a higher chance of making a purchase decision because awareness helps them clear their doubts about the brand. This research is in line with the research conducted by Kurniasari and Agung (2018) stated that brand awareness has an effect on purchasing decisions.

3) The influence of Social Media Marketing directly on Viral Marketing in Consumers of Janji Jiwa Coffee among Jabodeta Students.

Based on the results of the analysis of the influence of social media marketing on viral marketing, the Sig. Amounted to 0.012 with a beta coefficient value of 0.208 . Sig value. $0.012<0.05$. This result means that social media marketing has a significant positive effect on viral marketing. The magnitude of the influence of promotion through social media on purchasing decisions is 0.208 .

The results of this study have shown that promotion through social media has a significant positive effect on viral marketing. With promotions that are offered to innovate and be carried out properly, these promotions will go viral on social media by consumers. Thus this research is in line with the research of Farih et al. (2019).

4) Direct Influence of Brand Awarness on Viral Marketing to Consumers of Janji Jiwa Cofee among Jabodeta Students.

Based on the analysis of the effect of brand awareness on viral marketing, the Sig. As much as 0.000 with a beta coefficient value of 0.639 . Sig value. $0.000<0.05$. 
This result means that brand awareness has a significant positive effect on viral marketing. The magnitude of the influence of promotion through social media on purchasing decisions is 0.639 .

According to Chaffey, Mayer, Johnston, and Chadwick (2000) viral marketing refers to marketing techniques that seek to exploit pre-existing social networks to produce exponential increases in brand awareness. It can be said that with brand awareness the spread of viral marketing can increase. This research is in line with research from Mustikasari and Widaningsih (2018) which states that viral marketing can increase Brand Awareness.

5) Effect of Viral Marketing Directly on Purchasing Decisions on Consumers of Janji Jiwa Coffee among Jabodeta Students.

Based on the results of the analysis of the effect of viral marketing on purchasing decisions, the Sig. As big as 0,000 with a beta coefficient value of 0.222 . Sig value. $0.000<0.05$. This result means that viral marketing has a significant positive effect on purchasing decisions. The magnitude of the influence of promotion through social media on purchasing decisions is 0.222 .

Disseminating promotional information with a viral marketing system can improve consumer purchasing decisions, thus viral marketing can be a positive thing that a company can do for promotion. According to Farih et al. (2019) who state that the level of effectiveness of viral marketing is obtained from consumers' liking, so that consumers will make purchase decisions, these results are in line with this research. This research is in line with research from Wiludjeng and Nurlela (2013), Mustikasari and Widaningsih (2018) as well as Farih et al. (2019).

\section{Mediation Effect Test}

Sobel testused to test whether the effect of the intervening variable or indirect effect generated in the path analysis is significant or not. The Sobel test approach uses the standard error of the indirect effect coefficient (Sat), and to determine whether there is mediation or not, it can be done by calculating the $\mathrm{t}$ statistical value.

1) The influence of Social Media Marketing indirectly on purchasing decisions with

Viral marketing as an intervening variable on the Janji Jiwa Cofee among Jabodeta

Students.

The results of calculations using a calculation for sobel test (quantpsy.org) with the following results:

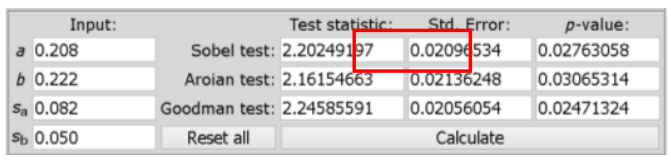

Figure 3 Sobel Test Results 1

Source: Calculation results quantpsy.org, 2020

The test results above show that the value of tcount $>$ ttable is $2.2025>1.9712$ with a significance level of 0.05 . The results of this study indicate that viral marketing is a significant intervening variable in relation to the relationship between social media marketing and purchasing decisions.

The effect of viral marketing as an intervening variable between social media marketing and purchasing decisions is $0.046(0.208 \mathrm{X} 0.222)$ or the amount of the indirect relationship in this study is 0.046 . When compared to a direct relationship which has an effect of 0.173 , it can be concluded that a direct relationship has greater influence.

Viral marketingproved to be a variable that mediates the influence of social media marketing on purchasing decisions. The proper use of promotion through social media is the essence of the formation of a viral marketing. Consumers who like and are satisfied with promotions on social media will influence viral marketing and also have an impact on consumer purchasing decisions. This research is in line with the results 
of research obtained by Farih et al. (2019) showing that its effect can be mediated by viral marketing.

2) The influence of Brand Awareness indirectly on purchasing decisions with Viral marketing as an intervening variable on the Janji Jiwa Cofee Consumers of the Soul among Jabodeta Students.

The results of calculations using a calculation for sobel test (quantpsy.org) with the following results:

\begin{tabular}{|c|c|c|c|c|}
\hline Input: & & Test statistic & Std. Error: & $\rho$-value \\
\hline a 0.639 & Sobel test: & : 3.79969245 & $0.0373-407$ & 0.00014488 \\
\hline$b 0.222$ & Aroian test: & 3.77416006 & 0.03758664 & 0.00016055 \\
\hline$s_{a} 0.087$ & Goodman test: & 3.82575014 & 0.03707979 & 0.0001303 \\
\hline$s_{b} 0.050$ & Reset all & & Calculate & \\
\hline
\end{tabular}

Figure 4 Sobel Test Results 2

Source: Calculation results quantpsy.org, 2020

The test results above show that the value of tcount $>$ ttable is $3.7997>1.9712$ with a significance level of 0.05 . The results of this study indicate that viral marketing is a significant intervening variable in relation to the relationship between brand awareness and purchasing decisions.

The effect of viral marketing as an intervening variable between brand awareness and purchasing decisions is $0.142(0.639 \times 0.222)$ or the magnitude of the indirect relationship in this study is 0.142 . When compared to the direct relationship which has an effect of 0.579 , it can be concluded that the direct relationship has a greater influence.

The existence of viral marketing as an intervening variable can strengthen the influence of brand awareness on purchasing decisions. Because if a company disseminates information or promotion (with a viral marketing system) about its products using the internet, it will increase and encourage purchasing decisions. This research is in line with Mustikasari and Widaningsih's (2018) research which states that viral marketing can mediate between variables.

\section{Conclusions and Recommendations \\ Conclusion}

Based on the results of the research description and discussion, the conclusions that can be drawn from this study are as follows:

1. Social media marketing directly has a significant positive effect on purchasing decisions.

2. Brand awareness directly has a significant positive effect on purchasing decisions.

3. Social media marketing directly has a significant positive effect on viral marketing.

4. Brand awareness directly has a significant positive effect on viral marketing.

5. Viral marketing directly has a significant positive effect on purchasing decisions.

6. Social media marketing indirectly has a significant positive effect on purchasing decisions through viral marketing.

7. Brand awareness indirectly has a significant positive effect on purchasing decisions through viral marketing.

\section{Suggestion}

Based on the description of the research results and conclusions, there are a number of things that are recommended to the parties related to this research as follows:

1. For It is hoped that Kopi Janji Jiwa will pay more attention to branding to increase brand awareness so that consumer interest and purchasing decisions will increase and to do better and more precise social media marketing by maximizing the effectiveness of viral marketing. 
2. For future researchers who want to research or continue this research, it is advisable to continue or develop this research by looking for other variables that can influence purchasing decisions in the context of social media marketing, brand awareness and viral marketing.

\section{References}

Ansari, S., Ansari, G., Ghori, M. U., \& Kazi, A.G. (2019). Impact of Brand Awareness and Social Media Content Marketing on Consumer Purchase Decision. Journal of Public Value and Administration Insights, 2 (2), 5-10.

Akbar, P. A., \& Sugiono, S. (2011). Analisis Pengaruh Kualitas Pelayanan, Hara, dan Lokasi Terhadap Keputusan Pembelian Sepeda Motor Honda (Studi Kasus pada Dealer Sepeda Motor Honda di Kota Banjarnegara). [Dissertation]. Semarang: Universitas Diponegoro.

Chaffey, D., Mayer, R., Johnston, K., \& Chadwick, F. E. (2000). Internet Marketing: Strategy, Implementation, and Practice. England: Pearson Education.

Chua, H. H., Rashid, K. A., Law, C. W., Hamizah, A., Khairul, A. H., \& Chua, K. B. (2010). A Fatal Case of Chikungunya Virus Infection With Liver Involvement. Medical Journal of Malaysia, 65(1), 83-84.

Durianto, D. (2004). Strategi Memimpin Pasar. Jakarta: Gramedia Pustaka Utama.

Farih, A., Jauhari, A., \& Widodo, E. (2019). The Effect of Promotion through Social Media on Decision Making in Pare English Course with Viral Marketing as an Intervening Variable. JMK (Journal of Management and Entrepreneurship), 4 (1), 41-60

Ghozali, I. (2013). Analisis Multivariate Program ( $7^{\text {th }}$ edition). Semarang: Badan Penerbit Universitas Diponergoro.

Hermawan, K. (2014). Perception of Motorcycles on Obligations To Use Standard Helmets in Kubu Raya District (Implementation Analysis in Article 57 Paragraph (1) Jo Paragraph (2) and Article 106 Paragraph (8) of Law Number 22 Year 2009 on Jalan Adi Sucipto, Kubu Raya Regency. SOCIODEV-Journal of Social Sciences (Social Development), 3 (3).

Kaplan, A. M., \& Haenlein, M. (2010). Users of the world, unite! The challenges and opportunities of Social Media. Business horizons, 53 (1), 59-68

Kemp, S (2020). Article : Digital 2020: 3.8 billion people use social media. Accessed on April 6, 2020 Retreived from We Are Social : https://wearesocial.com/blog/2020/01/digital-2020-3-8-billion-people-usesocial-media :

Kotler, P., \& Armstrong, G. (2004). Marketing. Praha: Grada..

Kotler, P. (2007). Manajemen Pemasaran, Analisis Perencanaan, dan Pengendalian (Edisi Bahasa Indonesia). Jakarta: Salemba Empat

Kotler, P. (2008). Manajemen Pemasaran (Edisi Milenium). Jakarta: PT. Prenhallindo.

Kotler, P., \& Armstrong, F. (2015). Principles of Marketing (15e Global Edition). Pearson.

Kurniasari, M., \& Budiatmo, A. (2018). The Influence of Social Media Marketing, Brand Awareness of Purchasing Decisions with Purchase Interest as an 
Intervening Variable at J. Co Donuts \& Coffee Semarang. Journal of Business Administration Science, 7 (3), 152-159.

Mustikasari, A., \& Widaningsih, S. (2018). The Influence of Viral Marketing toward Brand Awareness and Purchase Decision. In 1st International Conference on Economics, Business, Entrepreneurship, and Finance (ICEBEF 2018). Atlantis Press.

Rangkuti, F. (2004). The Power of Brands. Gramedia Main Library.

Rayport, J. (1996). The Virus of Marketing. Fast Company, 6, 68.

Riduwan, E. A. K., \& Kuncoro, A. (2012). Cara Menggunakan dan Memaknai Path Analysis (Analisis Jalur). Bandung: Alfabeta.

Ristania, N., \& Jerry S. J. (2015). Analisa Pengaruh Harga, Promosi Dan Viralmarketing Terhadap Keputusan Pembeli "Online shop" S-Nexian Melalui Facebook. Journal of Business Strategy and Execution, 5(2), 131-161.

Skrob, J. R. (2005). Open source and viral marketing. The Viral Marketing Concept As A Model For Open Source Software To Reach The Critical Mass For Global Brand Awareness Based On The Example Of Type, 3.

Suciningtyas, W. (2012). Pengaruh Brand Awareness, brand image, dan media communication terhadap keputusan pembelian. Management Analysis Journal, $1(1)$.

Sugiyono. (2011). Metode Penelitian Kombinasi (Mixed Methods). Bandung : Alfabeta

Sugiyono. (2016). Metode Penelitian Kombinasi (Edisi ke-3). Bandung: Alfabeta.

Suharno, Y. S. (2010). Marketing in Practice. Yogyakarta: Gandi Gebang Permai.

Syafizal, H. (2010). Analisis Data : Untuk Reset Manajemen dan Bisnis. Medan: Usu Press.

Wiludjeng, S. P., \& Nurlela, T. S. (2013). The Influence of Viral Marketing on Purchasing Decisions at $P T$ " $X$ ". Proceedings of the National Seminar and Call For Papers Sancall 2013. 